\title{
A Case Report: Cushing's Syndrome due to Bilateral Adrenalcortical Carcinoma
}

By

\section{Yoshimi MURAKami, M.D.}

From the Second Department of Internal Medicine, Faculty of Medicine, Kyushu University

A 43 year old male who was admitted to the Second Department of Internal Medicine of the Kyushu University Hospital because of general malaise and headache. Clinically he had moon-face, trucial obesity with buffalo-hump, cutaneous striae and edema, osteoporosis, polycythemia, eosinopenia, polyuria, albuminuria, glycosuria with hyperglycemia, hypokaliemia and hypocalcemia. Serum total cholesteral $316 \mathrm{mg} / \mathrm{dl}$ and urinary 17-Ketosteroid excretion $35 \mathrm{mg} / 24$ hours.

Postmortem examination revealed adenocarcinoma of bilateral adrenal corteces with pulmonary metastasis, Crooke's change of pituitary basophil cells, atrophy of Langerhans' islets, thyroid, parathyroid and testes. There was also intercapillary glomerulosclerasis.

\section{Study on the Extravital culture of the pulp of the Rabbits suffered from alloxan Diabetes}

\author{
By
}

\section{Masuda, M. Okumura}

Department of Medicine, Kyoto Pref. Med. Univ. (Director: Prof. S. Tateishi, M.D.)

We observed the extravital culture of the pulp of the rabbits suffered from alloxan diabetes and the effects on the extravital culture of the pulp of the normal rabbits by the additions of the glucose solutions and the serum of the rabbits suffered from alloxan diabetes.

1) The growth of the pulp of the rabbits suffered from alloxan diabetes is poorer than the normals.

2) The extravital culture of the pulp is controled by the addition of the serum of the rabbits suffered from alloxan diabetes.

3) When the serum of the rabbits suffered from alloxan diabetes is inactivited by the heat: filtered by the chamberland's filter $\mathrm{L}_{3}$ and absorbed by the absorbents (caorin and blood coal powder), its controllable power is reduced.

4) But, the dealed serum with those methods has the stronger controllable power than the non-dealed normals.

5) The dealed normal serum has the almost same controllable power as the non-dealed normal serum.

6) There is no intimate relationship between the control and the glucose concentrations. 


\title{
両側副腎皮質癌によるクツシング氏症候群の 1 例
}

\author{
九州大学医学部楠内科教室
}

村上義 視

\begin{abstract}
緒言
クッシング氏病の病因は兽て下垂体前葉の好塩基性細胞腫であるとされ212), 我教室て於ても光井の報告例

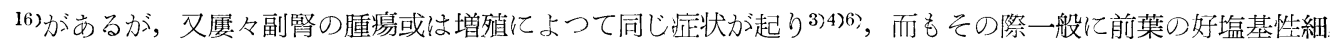
胞には硝子樣変性及び空胞化か認められ (Crooke 氏変性), 又前葉は組織学的に何らの異常を示さない事す ら市る事か明かとなり，従つて現在ではてれらはクッシング氏病（pituitary basophilism）とクッシング氏 症候群 (hypercorticoidism) とに分けて考えられている椂であるで8).

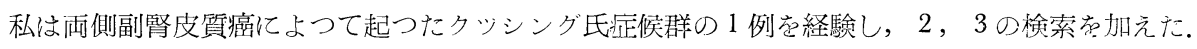

症例

43才 男 商業

主訴 頭重感, 頭痛, 肥満, 全身倦念及び歩行困難.

既往歴及び家族歴 特記ずべととを認めない.

現病歴 昭和25年春頃より急に肥満しはじぬ，翌昭和26年春から手足のむくみ，頭重感及び頭痛が起つた ので医師の診察を受け，血圧210で尿に蛋白があり，腎性高血圧といわれた，昭和27年秋頃より四肢の力が 弱まり，力仕事や長道を歩くことが難しく，又手に持つた品物をとり落したり，物仁躦いて転んだりする様 になつた，同年11月，高さ 2 尺位の縁側より転落して後頭部と春を打つたが， 2 週間位経つて両脚に脱力感

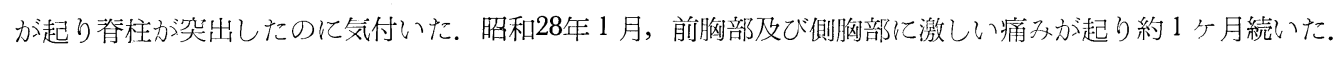
次いで 2 月頃より手足の先端がじんじんし始め, 又下 肢に力が入らず杖にすがつて歩かねばならない様にな つた。この頃より, 口渇多尿特に夜間多尿が現れた。 全身倦急，無力感，頭重感，頭痛，食思不振，不眠な ぞを訴え, 昭和 28 年 4 月20日当科に入院した。尚, 病 初より陰萎となつている.

現症第 1 図に示す如く特有の満月様顔貌て頸部及 び身區幹に著明な脂肪沈著があるが，四肢は外見紼くま た皮膚化紫色の大理石様紋理が著しい，皮膚裂線，多 毛症, 皮下及び粘膜出血はない, 下腿浮腫がある。

脈搏 90 , 整, 緊張良. 瞳孔, 視野, 眼底に異常存 認めない.

心は主として左に肥大し，血圧は最高170, 最低 102 $\mathrm{nm} \mathrm{mg}$ ，心電図で心室期外收縮，心筋変性，左室肥 大などの所見が認められる。肺レ線所見はない.

握力は左 12 , 右 $16 \mathrm{~kg}$ で腱反射は低下しているが病 的反射及び知覚障碍はない.

トルコ鞍は正常. 外見上龟背があり,レ線像で V, VI 及びXI胸椎に椎体の圧迫骨折が認められる。頭蓋骨に

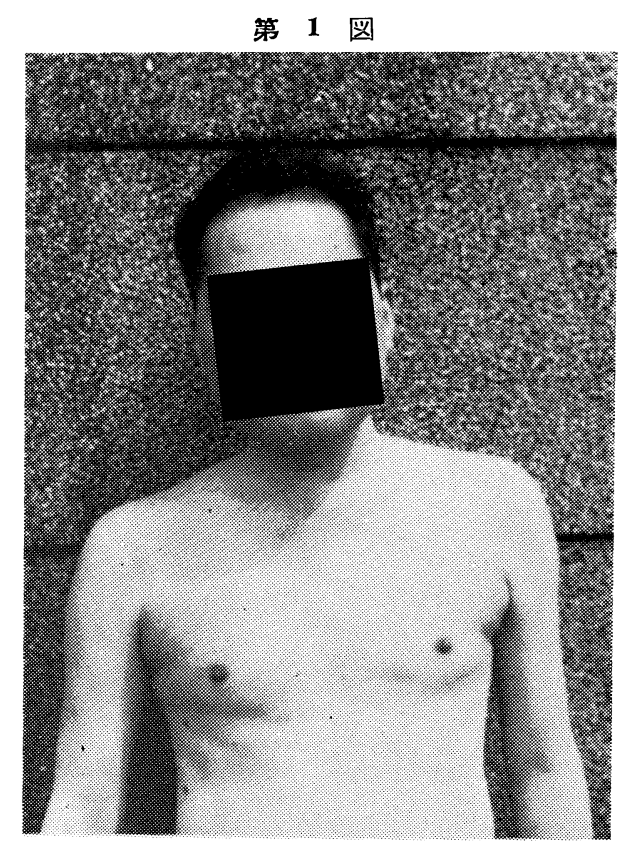


軽度の骨質粗鬆化か認められるが，骨盤及び四肢骨には異常はない，在足関節部に粘膜囊炎があり，瘦孔を 作つて治癒し難い。

外見上性器萎縮は認められない。

\section{臨床検査所見}

1) 尿所見 1 日尿量 $3 \sim 5 l$, 比重 1012 1015，蛋白 $0.3 \% ，$ 糖 1 日量 $80 \mathrm{~g}$ ，沈渣について夜間 12 時間 尿のAddis' count は尿量 $2270 \mathrm{cc}$, 赤血球 800,000 , 白血球及び上皮細胞 800,000 , 円柱 160,000 (殆どが硝子

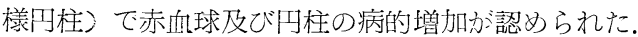

2) 血液所見 ヘモグロビン $108 \%$ (ザーリー), 赤血球 560 万, 血色素係数 0.96 , 白血球 10,400 でその百 分率往好中球桿核 10.0 ，分葉核 64.0 ，リンパ球 19.6 ，单球 6.2 ，好酸球 0.2 ，好塩基球 $0 \%$ でへマトクリット 值 $45 \%$ ，血小板数 21 万，出血時間 3 分 30 秒，ルンペル・レーデ現象陰性，赤沈 1 時䦭値 $24 \mathrm{~mm}$ （ウエスター グレン), 循環血液亘 $3,500 \mathrm{cc}$, 血清ワ氏反応陰性.

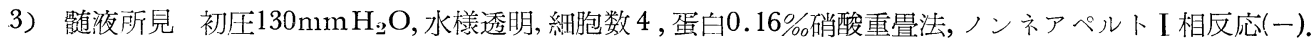

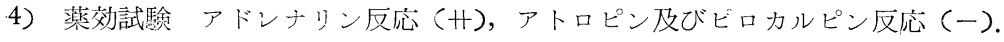

5）基礎代謝率くクニッピング法〉 $-24.3 \%$.

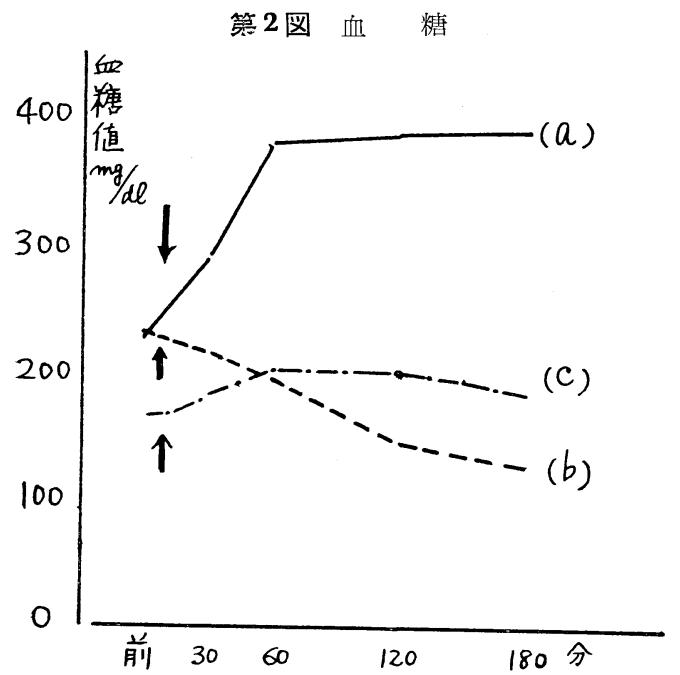

(a)：食慨性血糖(標準試験食米飯 $300 \mathrm{~g}$, 卵黄 2 個)

(b)：インシュリン血糖(空腹時インシュリン10単位 皮下注射了

(c)：アドレナリン血糖(空腹時アドレナリン $0.7 \mathrm{mg}$ 皮下注射，但し含水炭素制限食䭒摄取中〉

6）空腹時血糖值 $230 \mathrm{mg} / \mathrm{dl}$, 食餉性血糖標準試験 食米飯 $300 \mathrm{~g}$ 畉黄 2 個食後 2 時間目に $391 \mathrm{mg} / \mathrm{dl}$ 亿達 する。インシュリン10単位注射䆟 2 時間目には 139 $\mathrm{mg} / \mathrm{dl}$ となりインシュリン感性は正常で西る。アド レナリン $0.7 \mathrm{mg}$ 注射による過血糖は著明でない（以 上第 2 図).

ブドウ糖 2 重負荷試験でStaub 効果は認められな い(籍 3 図).

第 3 図 ブドウ糖 2 重負荷試験 (20\%ブドウ糖 $40 \mathrm{cc}$ 静注)

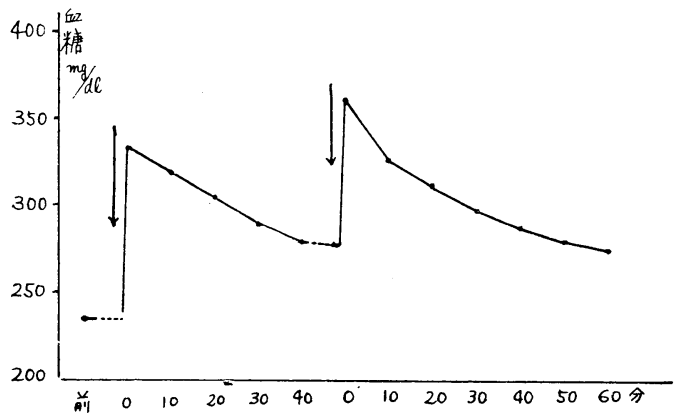

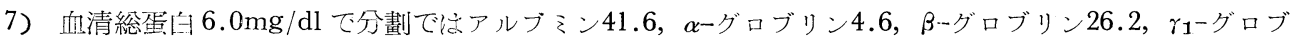

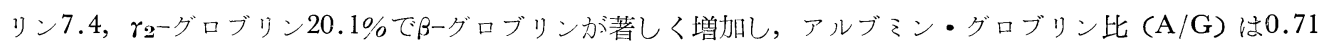
であつた。

8) 血清コレステロールは315mg/dlて著しい増加を示した。

9）副腎機能検査 アドレナリン $0.3 \mathrm{mg}$ 皮下注射による試験では好酸球数が少い( $0.5 \%$ ため堌減率は 明瞭でないが，ACTHーゲル20単位筋注による尿酸・クレアチニン比（u/c)の上昇率は90.6\%で正常であつ

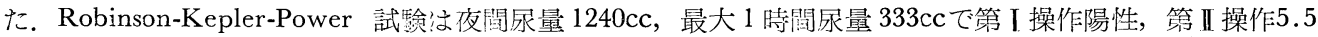
で同じく陽性でらつた。

尿中17ーケトスデロイドは1 日量26〜35mgで著しい増加を示した。 
10）血清カリウム $7.5 \mathrm{mg} / \mathrm{dl}$ ，カルシウム $7.9 \mathrm{mg} / \mathrm{dl}$ で共化著しく減少し，ナトリウム $194 \mathrm{mg} / \mathrm{dl}$, 無機燐 3.5, アルカリフォスファ ターゼ9.7笚位でほぶ正常值を示した。

11）血清モインングラハト 6 , 高田反応 陰性, 果糖負荷試験で過血糖面積65(H), BSP 試験 45 分後 $9.0 \%(+)$, 馬尿酸合成試験 (静注法) $45.2 \%$ ( 5 ).

12）血清残余窒素 $25.2 \mathrm{mg} / \mathrm{dl}$ ，尿素窒素 $18.4 \mathrm{mg} / \mathrm{dl}$, クロール $322 . \mathrm{mg} / \mathrm{dl}$ で標準尿素 クリアランス $36.7 \mathrm{cc} / \mathrm{min}(73.4 \%)$ ，クロー ルクリアランス $4.7 \mathrm{cc} / \mathrm{min}$.

PSP 試験 15 分 $22 \% ， 2$ 時間 $59 \%$.

Volhard 水試験では排泄遅延し (第 4 図), 渇試験は最高比重1016で濃縮力の低下が認められた.

手術

後腹膜腔内空気注入による副腎撮影で左副腎腫瘍（癌の疑い)と彰断して，九大外科で左副腎剔出術を行 つた.

術後不隠, 高熱, 意識润濁を来し，コルチゾン，DOCA，アドレナリンを用い，強心に努めたが術後31時 間目に死亡した.

昭和28年 7 月 8 日病理解剖を行つた.

\section{剖検}

1) 副腎 (第 5 図) 剔出寺左副腎は $10 \mathrm{~g}$ で, 黒 褐色を呈し表面は粟粒大黄色の斑点多数あり，右 副腎は $5 \mathrm{~g}$ ，両側共に皮質は㚒白色を帯び著しく 肥厚し稍々軟い．所々に小円形細胞の浸潤があり， 皮質細胞索㵔しく乱好酸性縕胞力゙多数市り， 核及び胞体の巨大なもの, 多核のもの, 不規則多 核形のものなどが認められ，一部は檤質内に不規 則に侵入している。被膜保たれ，外方えの破壊 性浸潤は見られない，髄質細胞は染色質の豊富な ものが多い.

2) 下垂体 正常大で前葉は著明に充血, 好塩 基性細胞に Grooke 変性が認められ又巨大細胞や
第 5 図 副腎皮質癌

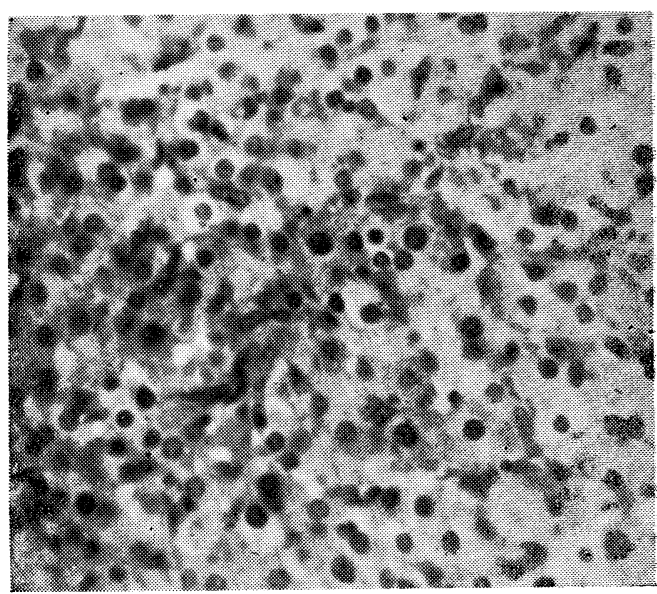

多核細胞がある(第6図). 後葉組織はや〉粗彭化せるもの〉様である。

3）腺 小且つ軟．実質細胞は委縮し間質脂肪組織增殖が認められ，ランゲルハンス島は大多数が完全に 硝子様変性を示し残余のものも萎縮が高度である.

4) 上皮小体 著しい萎縮が認められる.

5) 甲状腺 全般的に萎縮し，結節性甲状腺腫がある。

6）殬丸 高度萎縮. 一般に造精現象は極めて微弱である.

7) 肺右肺中葉に示指頭大豆 ゙゙卵円形灭白色の腫瘍があり，副腎皮質類似の外観を呈するが，弾性軟で

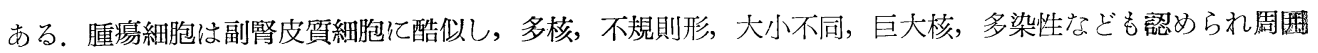
組織との境界は不明瞭である. 
8) 肝 霉漫性脂肪変性があり肝小葉の中心に於て著明.

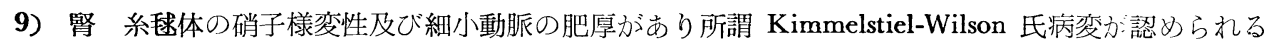
(第7図).

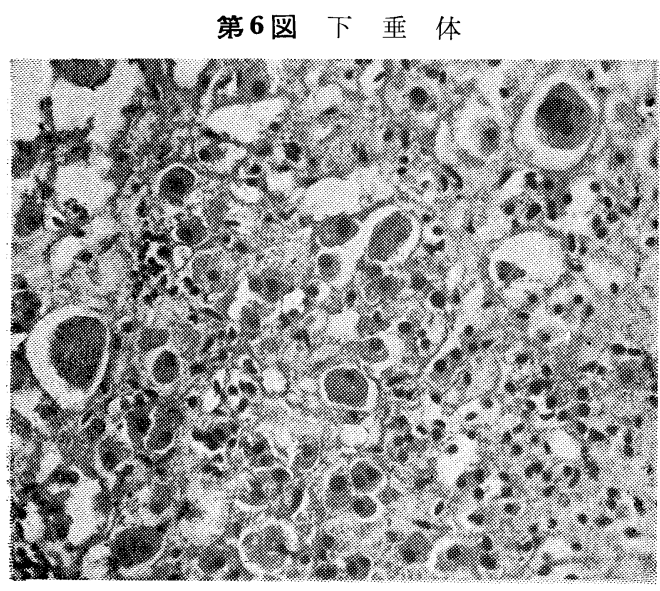

第7図腎 (Kimmelstiel-Wilson 氏病変)

好塩基細胞の空胞化, 硝子様変性及び巨核,

多核などが見られる。

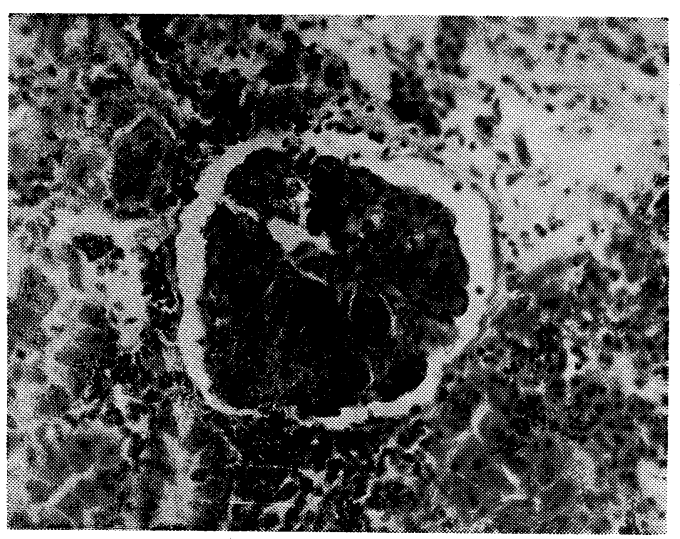

10）骨骼 脊椎は海綿骨梁が粗且つ小で萎縮が著明である. 頭蓋にも骨質粗琹化が見られる.

\section{考按}

クッシング氏症候群の臨床症状が副腎皮質ホルモンの分泌過剩によつて惹起される事は凮に知られた事で あるて 10). 仮説的には各々種類の異つた生物学的作用を有する各種の皮質ステロイドに対応する症状があり 得る筈であり, 実際 hypercorticoidism の多くは混合した症候群を示し, 分類上の基礎を見出す事が難しい といわれている.一般に本症候群に於て現れる症状は, 1) glycogenetic hormone (生長遅延, 筋薄弱, 毛 細皮膚脆弱化, 肥満, 骨質粗鬆, 窒素アナボリズム減少, 糖尿病性過血糖, インシュリン抵抗性)，2) 電解 質代謝ホルモン (高血圧, 多血症, 血清ナトリゥム増加，カリゥム減少)，3）Androgen 増加 (Hirstism, Acne, 卵巣機能不全)などにより説明し得る778).

本症候群の副腎の変化に就て Eisenhardt は副腎腫焬22例のうち16例は癌で残りの 6 例は良性腫瘍であつ たとい〉, 又副腎に腫瘍か溌見出来ない場合にも皮質機能九進を思わせる皮質増殖は常に存在し, それは細 胞索の肥厚として現れる事が多いという ${ }^{810 !}$.

この症例では雨側副腎皮質に不定型不規則の細胞増殖があり，右肺中葉の腫瘍と考え合せると，脑転移を 起した副腎腺癌と考えるのが妥当の様である. 元来副腎癌は門脈内転移が多いといわれているが，この症例 では肝腫瘍は見出し得なかつつた。

下垂体前葉つ硝子様変性はコルチ・゙ンの長期投与が同じ変化を起すとと，及び10才以前に始まつたクッシ ング氏症候群の全例が副袩腫愓に起因するものであつたというととから, 副腎皮質ステロイドの過剩分泌の 為て，前葉の ACTH 分泌が上行性に抑制された結果と考えられている8).

本症の骨質粗鬆化は一般に血中カルシゥム及び燐が正常值を示し, 又 Ostitis fibrosa generalisata を起さ ない事及び上皮小体は多く萎縮する事から，カタボリズムではなくアナボリズムによるもので，従つて血中 アルカリフォスファターゼは減少するといわれているが10)，ての症例では血中カルショムは減少し，アルカ リフォスファターゼは正常值を示した.

满ランゲルハンス甸の萎縮及びインシュリン感受性が認められ，真正糖尿病を考えさせるがこれは単なる 
合併症より密ろ本症に於ける多腺性病変の一つと見做すべきであろう。

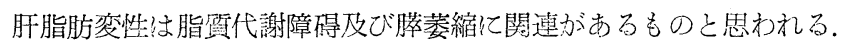

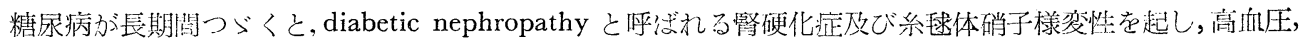
蛋白尿及び浮腫によつて特墔づけられる

Kimmelstiel-Wilson 氏症候群を現すといわれ ているが10)11)，乙の症例に於ても少〉る变化 が見出された.又との Kimmelstiel-Wilson 氏 病変を AGTH 投与行らて実踰的に起しえ たという報告がある寒往興味ある事である。

本症の水代謝障碍に就ては腎硬化及び糖尿 か関係すると考えるべきであらう。副婜皮質 ホルモンの利录作用に関与する程度に就て はにわが断定はし 難く, 又前葉ホルモン (Thyrotrophin) や闸状腺ホルモンの影蠁は 考え難い?

血清内カリゥム減少は Mineralo Corticotrophin 産生堌加によるものと思われるが， 塩化カリ投与後正常値に復し, 同時任全身倦 念消失して握力も著しく増加した事より，て の症例の筋力減弱は血清内カリゥム減少に帰 すべきであろう(第 8 図).

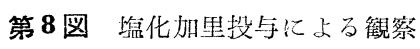

\begin{tabular}{|c|c|c|c|c|}
\hline \multirow[t]{2}{*}{ 時阎 } & \multicolumn{2}{|c|}{ 握力 } & \multirow[b]{2}{*}{$i$} & \multirow{2}{*}{ (EKG四肢誘導) } \\
\hline & 右 & t & & \\
\hline 前 & 16 & 11 & F EKG & 前 1 後 \\
\hline $15^{\text {分 }}$ & 19 & 15 & - $\mathrm{kCl} 5.0 \mathrm{gr}$ 内服 & \\
\hline $30 "$ & 19 & 17 & K KCO $50^{g r}$. 内服 & \\
\hline $45^{\circ}$ & 20 & 17 & 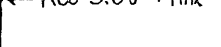 & II \\
\hline $60^{\circ}$ & 21 & 19 & & $\sim$ \\
\hline $75^{\prime \prime}$ & 20 & 17 & & \\
\hline $90^{\prime \prime}$ & 21 & 18 & $\leftarrow E K G$ & II \\
\hline $105^{\circ}$ & 21 & 18 & & $-\sqrt[4]{4}$ \\
\hline $120^{\prime \prime}$ & 21 & 19 & 湆 $\mathrm{K} \quad 13.0 \mathrm{mg} / \mathrm{dl}$ & \\
\hline $150^{\prime \prime}$ & 18 & 16 & & \\
\hline $180^{\prime \prime}$ & 20 & 14 & & \\
\hline $240^{\prime \prime}$ & 18 & 16 & $\therefore$ & \\
\hline
\end{tabular}

\section{結語}

副腎の癌によるクッシング氏症候群仁就ては本邦では沖中25), 屋形?7の記載があるが，私の経験した症例 は両側副腎皮質癌及び右肺転移を有し，手術後不幸にして死ししたものである.

本稿の一部は昭和 28 年 5 月日本内科学会儿州地方会（熊本）飞於て報告した。 叉, 病理解剖学的所見に就 ては九大病理学教室松井講師の御教示を頂いた。

御指導, 御校閲を睗つた恩師楠教授に感謝の意を捧げ, 又御鞭撻いただいた教室平田博士に衷心より御礼 を申し上げる。

\section{主 要 文 献}

1) Cushing: Bull. Jones Hop. Hosp. $50:$ 137, 1932.

2) Cushing: Arch. int. med., $51:$ 487, 1933.

3) Krans: Klin. Wschr. 1:361, 1934.

4) Baver: Klin. Wschr., $1: 361,1935$.

5) Kepler et al: J. Glin. Endocrinol. $8:$ 499, 1948.

6) Cahill: Endocrinology of Neoplastic Disease, New York, 1947. 7) Selye: Textbook of Endocrinology, Montriol, 1949. 8) Soffer: The Diseases of

Endocrine glands, 195, 1951. 99$)$ Williams: Textbook of Endocrinology, 1955.

Principles of Internalmedicine, 1955. グレンッゲビート，11: 469 (昭 12).

橋: 日本内科学会鹤誌，29: 741 (明17).

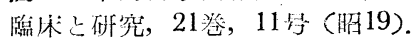
武部他: 東北医学嚾誌, 46 巻, 38 (昭 26 ) 䩕断々治燎，39卷，9，10号 (昭26). 飯塚: 臨床, 3 巻, 5 号 (明 26 ). 学, 8 巻, 84 (牟28). 医学のあゆみ别集, I (昭29).
11) Cecil: Textbook of Medicine, 1955.

13) 細茾: 日本内分泌学会雑誌, 16:27 (昭15).

15) 塩沢: 東北医学雑誌, $31: 507$ (鹏17).

17) 佐野他：日本内分泌学会雑誌，26巻，14 (将25). 19) 福田：臨床， 5 巻，248 (昭27).

21) 平福他: 日本病理学雑誌, 4 巻, 100 (昭 26 ).

23) 三宅: 臨休， 4 卷, 772 (胕27).

12) Horrison:
黑岩:

14) 高

16) 楠:

18)

20) 原沢他:

25) 沖中他：日本内分泌学会䊒誌，27巻，82(胉26). 26) 松浦:

27) 屋形: 内分泌， 2 卷， 1 号 (昭30). 